\title{
Do pro-poor schools reach out to the poor? Location choice of BRAC and ROSC schools in Bangladesh
}

Article

Accepted Version

Asadullah, M. N. (2016) Do pro-poor schools reach out to the poor? Location choice of BRAC and ROSC schools in Bangladesh. Australian Economic Review, 49 (4). pp. 432-452. ISSN 1467-8462 doi: https://doi.org/10.1111/1467-8462.12180 Available at https://centaur.reading.ac.uk/68828/

It is advisable to refer to the publisher's version if you intend to cite from the work. See Guidance on citing.

To link to this article DOI: http://dx.doi.org/10.1111/1467-8462.12180

Publisher: Wiley

All outputs in CentAUR are protected by Intellectual Property Rights law, including copyright law. Copyright and IPR is retained by the creators or other copyright holders. Terms and conditions for use of this material are defined in the End User Agreement.

www.reading.ac.uk/centaur

\section{CentAUR}


Central Archive at the University of Reading

Reading's research outputs online 
IZA DP No. 10326

Do Pro-Poor Schools Reach Out to the Poor? Location Choice of BRAC and ROSC Schools in Bangladesh

M Niaz Asadullah

October 2016 


\title{
Do Pro-Poor Schools Reach Out to the Poor? Location Choice of BRAC and ROSC Schools in Bangladesh
}

\author{
M Niaz Asadullah \\ University of Malaya, IZA, \\ University of Reading and SKOPE, University of Oxford
}

Discussion Paper No. 10326

October 2016

\author{
IZA \\ P.O. Box 7240 \\ 53072 Bonn \\ Germany \\ Phone: +49-228-3894-0 \\ Fax: +49-228-3894-180 \\ E-mail: iza@iza.org
}

Any opinions expressed here are those of the author(s) and not those of IZA. Research published in this series may include views on policy, but the institute itself takes no institutional policy positions. The IZA research network is committed to the IZA Guiding Principles of Research Integrity.

The Institute for the Study of Labor (IZA) in Bonn is a local and virtual international research center and a place of communication between science, politics and business. IZA is an independent nonprofit organization supported by Deutsche Post Foundation. The center is associated with the University of Bonn and offers a stimulating research environment through its international network, workshops and conferences, data service, project support, research visits and doctoral program. IZA engages in (i) original and internationally competitive research in all fields of labor economics, (ii) development of policy concepts, and (iii) dissemination of research results and concepts to the interested public.

IZA Discussion Papers often represent preliminary work and are circulated to encourage discussion. Citation of such a paper should account for its provisional character. A revised version may be available directly from the author. 


\section{ABSTRACT \\ Do Pro-Poor Schools Reach Out to the Poor? Location Choice of BRAC and ROSC Schools in Bangladesh ${ }^{*}$}

Non-formal schools play an increasingly important role in the delivery of educational services in poor communities, but little systematic evidence is available about their placement choices. We study location choice of "one teacher, one classroom" non-formal primary schools pioneered by BRAC vis-a-vis its first large scale replication under the government managed Reaching-Out-of-School (ROSC) project using school census data. Comparison is also made to another pro-poor educational institution - state recognized madrasas. We find that all three types of schools have a statistically significant presence in poor sub-districts within a district. However BRAC schools avoid pockets that lack public infrastructure and suffer from low female literacy rate while ROSC schools better target regions that have poor access to cities and roads, are less urbanized, more vulnerable to natural disasters, have fewer banks and working toilets. ROSC schools also have greater presence in regions that are under-served by government and government supported formal primary schools. On the contrary, the supply of BRAC schools and madrasas is significantly and positively linked to the presence of formal primary schools. Concerns over operational viability may explain why BRAC often leaves out remote regions where socio-economic circumstances are most likely to keep children out of school.

JEL Classification: 121, L31

Keywords: $\quad$ poverty, NGO, non-formal school, madrasa, Bangladesh

Corresponding author:

M Niaz Asadullah

Centre for Poverty and Development Studies (CPDS)

Faculty of Economics and Administration

University of Malaya

Kuala Lumpur 50603

Malaysia

E-mail: m.niaz@um.edu.my

\footnotetext{
* The paper was written while I was in receipt of a Leverhulme Trust research fellowship (from September 2011 to December 2012) on the rise of Islamic schools in Bangladesh and visiting the Research and Evaluation Division (RED) of BRAC as a Distinguished Fellow. I have benefited from discussions with Andrew Jenkins, Safiqul Islam, Imran Matin, Kaniz Fatema and Kazi Md. Mukitul Islam. I also thank three anonymous referees for helpful comments. The usual disclaimers apply.
} 


\section{Introduction}

Non-formal schools have become a popular option for education service delivery in poor communities around the world. In Bangladesh, Egypt, Ghana, Guatemala, Afghanistan and Mali, the complementary non-formal programs support small classes located in remote villages where rural children previously had almost no access to schooling (Waldman 2003; DeStefano et al. 2007). Studies show that non-formal schools effectively provide an alternative to formal primary education and succeed in maintaining and mainstreaming children into post-primary education (Sukontamarn 2005; Sud 2010). This has led international development partners to support expansion of the model in Asia (Tran 2012; Jacinto 2014; Unson 2015) and Africa (Department for International Development 2013). ${ }^{1}$ Bangladesh Rural Advancement Committee (BRAC), one of the world's largest non-governmental organisations (NGOs), runs a network of about 40,000 non-formal schools in Afghanistan, Pakistan, the Philippines, Uganda, South Sudan and Sierra Leone (Hossain and Sengupta 2009; Rosenberg 2013). However, the evidence on student performance in NGO-run schools is mixed. Some studies find positive impact (for example, Sukontamarn 2005; Khan and Kiefer 2007), while others report no or negative impact (for example, Arif and Saqib 2003). One possible explanation for differences lies in differential targeting rule. A negative or no impact could be driven by the fact that these schools do a better job in targeting the very poor and under-provided regions, which in turn lower the average level of student achievement compared to mainstream schools serving betteroff regions.

In this context, Bangladesh offers an interesting case study for research on location choices of non-formal schools. Home to a large number of NGOs, the country has made exceptional progress in human development over the past two decades (Asadullah, Savoia and Mahmud 2014; UNDP 2013). Gender parity in school enrolment has been achieved in partnership with one of the oldest non-formal schooling systems in the world-BRAC-run 'one teacher' school. ${ }^{2}$ Started in the mid1980s, this schooling system served as a model for many other community-based, NGO-supported programs providing primary education to children from disadvantaged social backgrounds. Considered the largest non-formal school system in the world (Smith, Fraser and Schauerhammer 2015), BRAC schools account for 76 
per cent of all NGO primary schools in Bangladesh (Kabeer, Nambissan and Subrahmanian 2003). This has led the Bangladeshi Government to scale up a modified version of the BRAC model under the 'Reaching-out-of-school' (ROSC) project. These non- or semi-formal schools provide a low-cost platform to target children currently out of school and living in difficult-to-reach communities. Bangladesh is also home to another low-cost schooling option. Thousands of staterecognized primary madrasas (i.e. Islamic schools) operate in rural areas alongside NGO schools to serve poor households. Together, NGO, ROSC and madrasa schools account for nearly one-tenth of the total primary school enrolment in the country. However, little evidence is available on the choices of these three pro-poor schools.

Common perception is that location choice of BRAC schools is driven by a social agenda, as well as cost considerations. Bangladesh Rural Advancement Committee's education program allegedly began in rural areas where there was no alternative to state-provided formal education (Ardt et al. 2005). These schools are viewed by many as making up for the failure of the government to set up enough public schools (Waldman 2003). International media commentaries also laud BRAC for setting up the world's largest private, secular school system in remote rural villages and providing a safety net for children who drop out of state schools or who have not had a chance to attend school at all (The Economist 2012; ${ }^{3}$ Rosenberg 2013; Macmillan 2015). Similarly, madrasas are widely believed to target regions where public schools are under-provided (Evans 2006) and attract children from poor families (Griswood 2005; Asadullah, Chakrabarti, and Chaudhury 2015; Asadullah and Chaudhury 2016). An important deterrent to schooling for the poor is the inadequate number of schools and the consequent distance between the average residence and a school. In countries with poor social infrastructure in rural areas, NGO-run schools and madrasas arguably fill an important void. Therefore, a comparison of BRAC schools with its replication, not-for-profit ROSC schools, and Islamic schools provides an indirect way to examine the primary motivation of location choices of the former.

This research is related to the small literature on the determinants of non-state school locations (Downes and Greenstein 1996; Barrow 2002; Downes and Greenstein 2002; Pal 2010). Downes and Greenstein (1996) find that private schools in the state of California with different religious affiliations respond differently to population 
characteristics, which is evidence of differences in the objectives of these different types of private schools. In a related study, Downes and Greenstein (2002) examine the location choice of private schools entering the Californian schooling market and find that the correlates of the location choices of entrants appear to be the same as the determinants of the location pattern of incumbent private schools. In contrast to Downes and Greenstein, Barrow (2002) finds a significant negative relationship between private school counts and average household income of the community. I contribute to this literature by presenting evidence on the determinants of nonmadrasa private schools and madrasas in Bangladesh. As a by-product, this article also makes a contribution to the literature on NGO program placement (Sharma and Zeller 1999; Ravallion and Wodon 2000; Fruttero and Gauri 2005; Brass 2012; Mallick and Nabin 2011) and targeting of educational programs (Van Domelen 2007; Essuman and Bosumtwi-Sam 2013) in developing countries.

I follow Downes and Greenstein (1996) and compile a dataset on the characteristics of the sub-districts in which primary schools are located throughout Bangladesh. The empirical analysis is based on a hybrid dataset that combines information from two Census datasets covering all registered primary and secondary schools, with information on local poverty, literacy rate, and road, banking and sanitary infrastructure. I use this unique dataset to test whether BRAC and ROSC schools favour poor sub-districts and target regions where public schools are under-provided. The results indicate that the characteristics of the population and other competing primary schools influence location decisions. First, compared to madrasas and BRAC schools, ROSC schools are found more in poor areas. Second, even after controlling for all other factors, poor access to sub-district infrastructure facilities is associated with a higher likelihood of having a ROSC school in the sub-district. Third, ROSC schools are more likely to be in areas with under-supply of government formal schools, where children have greater likelihood of being out of school. In contrast, while BRAC schools also show significant correlation with local poverty, their location choices are less sensitive to the lack of public infrastructure availability and unavailability of mainstream formal schools. As a matter of fact, BRAC schools (and madrasas) have a greater presence in sub-districts that already benefit from large number of formal government and government-aided non-government primary schools and benefit from higher female literacy rate. 
The rest of the article is organised as follows. Section 2 explains the Bangladeshi education system, with a focus on BRAC schools and ROSC program. Section 3 describes the conceptual framework and the empirical strategy. Section 4 describes the dataset used in this study. Section 5 presents the main results. Section 6 concludes by spelling out the policy implications of the findings.

\section{Background: BRAC Schools and the ROSC Program in Bangladesh}

The Bangladeshi education sector has a complex structure, where the composition of the sector changes as one moves from pre-primary to secondary levels. Primary education in Bangladesh spans grades 1-5 and falls under the purview of the Ministry of Primary and Mass Education. Over 18 million students are currently enrolled in around 14 types of schools (Table A1). There are at least 13 types of primary schools in Bangladesh. Of these, 37,672 are government and 21,366 are registered nongovernment schools and together they account for nearly 60 per cent of all primary schools and 80 per cent of all enrolled children in the country (Directorate of Primary Education 2012a). These two categories provide the platform for BRAC, ROSC and madrasa schools to operate. The BRAC and ROSC schools represent 1.62 per cent and 0.91 per cent, respectively, of the total enrolment. Adding Madrasa schools to these two, the three pro-poor schools altogether account for 9.28 per cent of the total primary enrolment in Bangladesh.

Many mainstream formal schools suffer from various governance problems such as corruption, lack of transparency and inefficient use of resources. In addition, some often leave out children in remote communities. In response to these problems, the non-formal schooling system has been developed to provide 'second chance' education to those left out of the formal education system. Generally, it targets some selected demographic sub-groups. Starting in the late 1970s with the Escuela Nueva program in rural Colombia (Psacharopolous, Rojas and Velez 1993; McEwan 1998), the non-formal schooling movement has spread in many developing countries. Historically, non-formal education initiatives have been implemented in diverse forms such as farmer training programs, adult literacy programs and various community programs of instruction in health, family planning and so on (Coombs and Ahmed 
1974). Arguably the largest and most successful non-formal education system was introduced in Bangladesh in 1985 by BRAC (Chabbot 2006). Later in 2000-2001, the program was scaled up to cover the entire 5 year primary school curriculum through a 4 year, catch-up program. BRAC's education programme is now universally recognised as a low cost but effective model to educate children who are not covered by formal school systems (Bangladesh Rural Advancement Committee 2009). BRAC annual report 2009 states that "Our non-formal schools offer flexible timings and entry ages, small-sized classes taught by a female teacher from the community, free educational materials, hands-on teaching with student participation and little homework or long holidays, to accommodate children who never enrolled, or had to drop out of regular schools”. Other similar programs include the Community School program in Egypt in the early 1990s (Farrell 2004) and the School for Life program in Ghana in the late 1990s (Hartwell 2006). These programs are usually operated by non-state providers with strong community participation, they have low operational costs and they cater to hard-to-reach students who remain excluded from the formal education system for various reasons. ${ }^{4}$

According to the non-formal education mapping carried out on behalf of the Bureau of Non-Formal Education (BNFE), there were 1.4 million students in over 53,000 centres in 2007 in Bangladesh (Directorate of Primary Education 2012b). However, majority of these centres belong to BRAC which also franchises its model by subcontracting to 200 small NGOs to deliver non-formal education programs. A BRAC school consists of one teacher and one classroom that caters to out-of-school and/or usually marginalised children. Although BRAC schools and government public schools teach the same competency-based curriculum, there are three key operational differences between these schools: (i) student intake occurs every 4 years at the former but annually at the latter; (ii) the average class size is 25-30 students at the former but more than twice at the latter; and (iii) while the former averages 4,091 contact hours per primary cycle, the corresponding figure at the latter is 4,046 (Chabbott 2006). At the same time, BRAC schools have higher attendance rate (96 per cent) and completion rate (94 per cent) than government public schools (61 and 67 per cent, respectively) and BRAC students have higher test scores across several different subjects including life skills, reading, writing and numeracy. ${ }^{5}$ 
Inspired by the 'success' of the BRAC model, the Bangladeshi Government brought the Reaching Out-Of-School Children (ROSC) program into the formal schooling system and expanded it on a large scale (Ahmed 2006). ${ }^{6}$ Managed by the government's Directorate of Primary Education and supported by the World Bank, local learning centres provide non-formal education to out-of-school children of ages 7-14 years. ${ }^{7}$ Like BRAC schools, most of the teachers are women, locally recruited and most have secondary school certificate-level education. Beneficiary students come from the 90 poorest sub-districts (upazilas) of the country. The primary program objective is to bring out-of-school children into education through learning centres, called Ananda Schools (or 'schools of joy'). Therefore, ROSC non-formal program also includes financial incentives in the form of stipends to underprivileged students, conditional on their school enrolment and performance. ${ }^{8}$ This also includes free books, stationery and school uniforms and helps offset the opportunity cost for working children. Since its inception in 2005, ROSC schools have provided 'second chance' primary education to about 5 million children, half of whom are girls, through more than 23,000 learning centres (UNICEF 2009). ${ }^{9}$

Existing studies on non-formal schools in Bangladesh and other developing countries have focused on relative performance of students vis-à-vis those in formal schools. The evidence so far is mixed (for example, Arif and Saqib 2003; Sukontamarn 2005; Asadullah, Chaudhury and Dar 2007; Khan and Kiefer 2007). One explanation for the observed difference in findings relates to differential regional concentration of schools. Poor performance of students in non-formal schools may reflect the fact that these students belong to poor and under-developed locations, compared to those in formal schools. In this article, I therefore investigate the location choice of ROSC schools using Census data from Bangladesh. To my knowledge, this study is the first to evaluate the placement decision of a large-scale, government-financed, non-formal school program. I do not know of any previous NGO-led non-formal program that has been replicated and mainstreamed into the formal primary education system by the government. Therefore, these findings have much relevance for other countries that plan to undertake similar replications, given the rising popularity of non-formal schools. 
Lastly, for comparison purposes, I also examine location choice of ROSC and BRAC schools vis-à-vis registered madrasas operating at primary level in Bangladesh. Similarly to BRAC schools, madrasas are entirely in the non-state sector, although their curricula follow government regulations as prescribed by the Madrasa Education Board of the government (Asadullah and Chaudhury 2009). Students are taught subjects similar to those taught in general education primary schools in addition to a curriculum of religious and Arabic studies. Evidence on the determinants of madrasa enrolment in Bangladesh confirms a strong poverty connection, suggesting that madrasas are pro-poor (Asadullah, Chakrabarti and Chaudhury 2015).

\section{Conceptual Framework and Methodology}

Although little is understood about how non-state schools make location decisions, common perception is that they generally choose to locate where there is undersupply of mainstream schools (Waldman 2003). Non-profit institutions often seek to satisfy the demand for specific public goods that are not demanded by the median voter and therefore are not provided by government (Weisbrod 1975). Nongovernmental organisations are essentially not-for-profit organisations devoid of government involvement, staffed by altruistic employees and volunteers working towards ideological, rather than financial, goals (Werker and Ahmed, 2008). Nonprofits may be perceived to be more trustworthy due to the non-distribution constraint (of profits). For these reasons, they may enjoy a competitive advantage in service delivery a number of areas (Glaeser and Shleifer 2001). NGO schools are also particularly attractive to the poor because of low (or no) student fees. In case of forprofit private schools, affordability is an important consideration if parents are to choose fee-paying private schools (as against tuition fee-free state and/or non-formal schools). In the United States, private school count is positively related to mean family income of the locality (Barrow 2002). Thus, local poverty may play an important role: I expect that the share of non-formal, non-state schools will be higher in economically poorer sub-districts. At the same time, NGO schools may choose regional pockets within an otherwise poor district which have superior non-education public infrastructure (for example, roads) as it saves on operation costs and hence is important for financial viability. Taken together, not-for-profit NGO schools should thrive in areas where demand for fee-charging schools is low and/or the supply of 
alternatives is limited, although they may avoid geographically remote pockets for program sustainability-related reasons. In this context, understanding the larger decision regarding NGO branch placement is important.

To the extent that NGOs, like BRAC, operate educational services in areas with existing development programs, location of NGO schools would mimic that of NGO branches. The common perception is that NGO branches are placed in povertystricken communities (Ravallion and Wodon 2000). However, the literature on NGO branch placement lacks consensus on the issue. ${ }^{10}$ Using sub-district level data to analyse the geographical placement of three credit programs, Sharma and Zeller (1999) present evidence that NGO branches in Bangladesh tend to be located in poor pockets of relatively well-developed areas rather than in remoter, less-developed regions. Fruttero and Gauri (2005) use nationally representative household survey data for 1995-2000, a period when the NGO sector expanded throughout the country. They found little evidence to support the view that NGO programs in a community are related to community needs. The authors also found that NGOs established new programs where they themselves had no program previously, irrespective of whether other NGOs were already present in the community. Simultaneously examining BRAC, ROSC and madrasa school location data therefore allows us to understand operational motives for BRAC school placement.

The BRAC schools require minimal physical infrastructure (for example, one room with a floor space of approximately 31.21 square meter). There are only 33 students, on average, and one teacher in a school (Nath 2002). However, one constraint that may limit entry of these schools in educationally backward locations is the supply of educated women (Chabbott 2014). An internal study by BRAC lists four factors as the determinants of location choice of a BRAC school: (i) the availability of a teacher in the particular village; (ii) the number of boys and girls of particular age group who need education; (iii) the availability of a 'bari' (that is, a cluster of households) where a room may be rented for the school; and (iv) the availability of married, educated women (Rashid, Chowdhury and Bhuiya 1995). The majority (that is, 97 per cent) of teachers in BRAC schools are married women and they come from the village that the school is in. They are required to have completed at least 9 years of schooling and 
attend a 15 day teacher training course before they are allowed to teach in a BRAC school (Ardt et al. 2005). ${ }^{11}$

Taking into account the above discussion, this empirical analysis focuses primarily on two arguments. First, ROSC schools are driven by a common mission to serve the poorest in rural areas. These schools have been designed for sub-districts with high poverty and low enrolment and completion rates (Sarr et al. 2010). Sub-districts were chosen for the ROSC project based on a net enrolment rate that was lower than 85 per cent. Once this screening criterion was satisfied, selected upazilas had to fulfil two out of three of following selection criteria: (i) the gender gap in enrolment should be greater, at least, than 2 percentage points; (ii) the primary completion rate should not exceed 50 per cent; and (iii) the poverty rate should be above 30 per cent (ROSC Project Office Unit 2009). If this was the case, ROSC schools should be found in locations with above-average poverty levels where out-of-school child population is more likely to concentrate. Since the program is government-managed, location choice of ROSC schools is likely to be less affected by concerns over financial viability. If so, comparing ROSC location with that of NGO and madrasa schools can help identify non-market motives for the latter group of schools.

Second, location choice should be insensitive to the availability of public infrastructure in the locality if ROSC schools are truly poverty-focused. To be precise, infrastructure variables are expected to be negative and significant predictors of location choice. On the other hand, BRAC schools will avoid very remote pockets in a poor region as this would increase operational cost and affect program viability for reasons such as the unavailability of married, educated women in the same village where the school is to be set up. Better access to public infrastructure could minimise the cost of operation (greater supply of local teachers) and ensure a high return to private investment. For India, Pal (2010) argues that the presence of certain local public infrastructure encourages the rise of private schools in Indian districts as it saves on private school production costs. ${ }^{12}$ Following Pal (2010), I additionally examine whether the share of BRAC schools is higher in sub-districts with more infrastructure facilities, compared to ROSC schools. 
To formally test these two hypotheses, I estimate regression models where the main dependent variable is defined as current stock of BRAC schools in the region. I define the sub-district (that is, upazila) to be the relevant education market. Given that the outcome variable assumes count data, the determinants of the number of school locations are modelled using Poisson regression. In this sense, the empirical approach is similar to that of Downes and Greenstein (1996). In the regression function, the two key right-hand-side variables are: (i) lagged income of the region; and (ii) proxies for public infrastructure in the region. The former is proxied by population below the poverty line in the region. Proxy measures for infrastructure include variables such as travel distance to the capital (that is, Dhaka), distance from nearest road, literacy of household head, households with access to good toilet and local financial development (measured in terms of total number of bank branches). In order to ensure that the infrastructure variable is not picking up the effect of geography, I additionally control for 'exposure to natural disaster'. Smaller habitation size can reduce the optimum school size and therefore limit the scope for schools to operate. ${ }^{13}$ Moreover, in a sparsely populated region, more schools (of small size) would be needed. Therefore, all regressions control for school-aged population in the sub-district.

If the poverty hypothesis is valid, the coefficient on local income in the location regression will be negative. A positive coefficient will be obtained if BRAC schools behave like for-profit schools and target areas that will help them meet operating costs. However, if BRAC schools only target poor districts instead of poor pockets in well-off areas, the coefficient on local income variable will be insignificant once controls for district fixed effects are in place.

Poor provision of public infrastructure can also take the form of lack of government and government-aided schools. Total number of government schools can exert a positive influence if practical considerations are the primary determinant of location choice. ${ }^{14}$ Similarly, I consider the possible effects of government school non-teaching inputs, including type of government school building (pucca or not) and school's access to drinking water, on the share of BRAC schools in the region. ${ }^{15}$

Lastly, I repeat the regression analysis using counts of ROSC and madrasa primary schools as dependent variables. This allows us to compare and contrast estimates of 
BRAC location regression models with those for other types of pro-poor schools and to test whether BRAC location choices follow that of other non-formal schools (that is, ROSC schools) or whether they are more similar to existing formal pro-poor schools (that is, madrasa schools).

\section{Data and Descriptive Statistics}

\subsection{Data Source and Sample Construction}

Research on school location choice is rare for developing countries because large spatial datasets containing information on schools by location alongside other school characteristics are not available in public domain. To overcome this data problem, I combine Census data on schools with information on regional characteristics to create a hybrid dataset. Each year, grade 5 students of all primary schools in Bangladesh participate in a national examination at the end of the schooling cycle. The primary source of these data is the primary school Terminal Examination of 2011. For crossvalidation purposes, I also use another independent Census dataset-Annual School Census (ASC) - that is used by the government for monitoring purposes.

Table A1 provides a breakdown of primary schools in Bangladesh by major type. When compared to national examination data-based counts, ASC records agree broadly with Terminal Examination data on the total number of government schools, aided schools, ROSC schools and secondary attached schools. However, for most other school types, ASC data turn out to be significantly underestimated. This is particularly true for government-aided schools, private schools and madrasa and BRAC schools. The Terminal Examination records suggest a total of 99,351 primary schools (against 89,707 in ASC) in Bangladesh. This creates an upward bias in the percentage share of government primary schools in the ASC data. While 2011 ASC is an alternative source of rich school-level data, the survey underestimates counts of various types of schools. ${ }^{16}$ For this reason, the main quantitative analysis in this article is based on the Terminal Examination dataset. Nonetheless, I present supplementary evidence based on 2011 ASC data. In the empirical analysis, schoollevel data are aggregated at the sub-district (thana) level, the unit of observation. Once aggregated at the sub-district level, sub-district data on various types of schools for the year 2011 were mapped on to sub-district-wide indicators of poverty level and 
infrastructure. The latter data were obtained from various sources (as explained later). Lastly, in order to assess location decisions as a function of the supply of secondary schools, I use lagged data from 2003 Bangladesh Bureau of Educational Information and Statistics School Census.

\subsection{Descriptive Statistics}

Information relating to institutional structure of ROSC, BRAC and madrasa schools (in terms of availability of teachers and size of student enrolment) is presented in Table 1. For comparison, data are also presented on for-profit and government schools. Private schools have most favourable student-teacher ratio (STR), which in most cases is below the government-prescribed limit of 46. Compared to government and non-government schools, however, student-classroom ratio (SCR) is bigger, suggesting that these schools comprise relatively fewer classrooms. The BRAC and ROSC schools, owing to their non-formal nature, have a student population averaging between 30 and 35. The SCR and STR for these two categories are uninformative as each is organised in a single room and managed by a single teacher. In case of madrasas, SCR is very high, although they enjoy a favourable STR. In other words, madrasas adopt a more labour-intensive approach to school management, employing more teachers and fewer classrooms. ${ }^{17}$ Of all types, government schools appear to be over-subscribed across all divisions, as confirmed by the total enrolled student population.

The observed differences in inputs contrast with differences in student performance of various schools in 2011 Terminal Examination (see Table 1). Despite small STR, students of ROSC and madrasa schools have lower pass rate, compared to government and non-government schools. Private school students, on the other hand, enjoy high pass rate (93.6 per cent), consistent with a very low STR of 12.9. Yet, there is a big performance gap between BRAC and ROSC schools despite the fact that they both enjoy small STR (28 and 32, respectively). The pass rate of BRAC students is 95 per cent, while that for ROSC students is 46 per cent. The poor performance of ROSC students in national examination could be partly owing to the fact that they largely come from poorer socioeconomic background. ${ }^{18}$ Moreover, they are often in disadvantaged regions that are discarded by formal government, as well as BRAC-run non-formal schools. ${ }^{19}$ I examine this by studying the correlation between counts of 
Table 1 Average Number and Characteristics of Schools in the Sub-District by Type ${ }^{\mathrm{a}}$

\begin{tabular}{|c|c|c|c|c|c|c|c|c|}
\hline School type ${ }^{c}$ & $\begin{array}{l}\text { Average } \\
\text { number of } \\
\text { schools } \\
\end{array}$ & $\begin{array}{c}\text { Average number } \\
\text { of schools per } \\
\text { 1,000 children } \\
\text { (6-10 years) }\end{array}$ & $\begin{array}{c}\text { Average } \\
\text { school size } \\
\text { (number of } \\
\text { students } \\
\text { enrolled) } \\
\end{array}$ & $\begin{array}{c}\text { Average } \\
\text { number of } \\
\text { students } \\
\text { per } \\
\text { classroom } \\
\end{array}$ & $\begin{array}{c}\text { Average } \\
\text { number of } \\
\text { students per } \\
\text { classroom } \\
\leq 40\end{array}$ & $\begin{array}{c}\text { Average } \\
\text { number of } \\
\text { students per } \\
\text { teacher } \\
\end{array}$ & $\begin{array}{l}\text { Average } \\
\text { number of } \\
\text { students } \\
\text { per teacher } \\
\leq 46 \\
\end{array}$ & $\begin{array}{l}\text { Proportion } \\
\text { of schools } \\
\text { in remote } \\
\text { location }^{b} \\
\end{array}$ \\
\hline \multicolumn{9}{|l|}{ Non-formal school } \\
\hline BRAC $^{\mathrm{d}}$ & 48.61 & 1.42 & 34.21 & 30.02 & 0.99 & 28.38 & 1.00 & 0.06 \\
\hline ROSC $^{\mathrm{e}}$ & 4.55 & 0.10 & 31.57 & 32.81 & 0.97 & 32.79 & 0.99 & 0.16 \\
\hline \multicolumn{9}{|l|}{ Formal school } \\
\hline Government primary school & 75.27 & 2.37 & 283.73 & 67.68 & 0.22 & 53.30 & 0.46 & 0.32 \\
\hline Non-government registered school & 42.67 & 1.36 & 190.34 & 65.53 & 0.20 & 54.55 & 0.48 & 0.36 \\
\hline Private school & 22.14 & 0.59 & 116.46 & 79.36 & 0.33 & 12.95 & 0.99 & 0.09 \\
\hline Primary madrasa & 23.20 & 0.68 & 214.07 & 117.68 & 0.14 & 33.69 & 0.80 & 0.12 \\
\hline
\end{tabular}

Notes: (a) Data reported in columns 3-8 are from 2011 Annual School Census.

(b) Remote locations include haor, char, coastal and hilly areas.

(c) Data on primary schools, except Bangladesh Rural Advancement Committee (BRAC), are from 2011 Terminal Examination.

(d) Data on total number of BRAC schools are for the year 2006 and are provided by BRAC Education Program.

(e) ROSC denotes Reaching-out-of-School. 
government and non-government registered primary schools with respect to government and aided schools.

Table 2 presents the correlation matrix. Most of the correlation coefficients are positive, implying that areas that are educationally developed attract all types of schools. The only exception is private schools. The corresponding coefficients are small in size and significant when calculated with respect to schools that are perceived to be pro-poor; namely, BRAC (0.08), ROSC (-0.01) and primary (0.06). Amongst 'pro-poor' schools (that is, BRAC, ROSC and primary madrasa), the correlation coefficients are always large and positive. At the same time, correlation coefficients for BRAC schools are also very large and significant with respect to government and government-aided schools. This suggests that BRAC caters to dropouts from formal schools. On the other hand, compared to BRAC and madrasa schools, ROSC schools show smallest correlation with government primary schools, registered non-government primary schools and private schools. At the same time, they have significant correlation with BRAC and madrasa schools (correlation coefficients being 0.25 and 0.22 , respectively). On the other hand, the correlation coefficient between BRAC school, with respect to government primary school, is threefold larger (0.37), compared to that of ROSC. Lastly, correlation coefficients for primary madrasas have very high values with respect to 'non-poor' schools; that is, government schools (0.58) and registered non-government schools (0.62). These correlations are much higher when compared to those of ROSC schools (0.22) and BRAC schools (0.41).

In summary, it appears that BRAC, ROSC and madrasa schools are less resourceintensive and have a larger presence in rural areas. Therefore, they are strategically better placed to thrive in poor communities, compared to for-profit private schools. The primary objective is to test whether there is a correlation between location choice and incidence of poverty. In addition, I want to test whether BRAC schools locate themselves in areas with under-provision of formal schools or in poorer regions where key public infrastructure is lacking. If the former, ROSC location factors should be similar to that of BRAC schools. If the latter, it should be similar to conventional schools and madrasas. The next section discusses the regression results. 
Table 2 Correlation Matrix for School Count Variables (pair-wise correlations between variables)

\begin{tabular}{|c|c|c|c|c|c|c|}
\hline School type & $\begin{array}{c}\text { Government } \\
\text { primary } \\
\text { school } \\
\end{array}$ & $\begin{array}{l}\text { Registered non- } \\
\text { government } \\
\text { school }\end{array}$ & $\begin{array}{l}\text { Private school } \\
\text { (kindergarten) }\end{array}$ & $\operatorname{ROSC}^{a}$ & Madrasa & $B R A C^{b}$ \\
\hline Government primary school & 1.00 & - & - & - & - & - \\
\hline \multirow{3}{*}{$\begin{array}{l}\text { Registered non-government } \\
\text { school }\end{array}$} & 0.44 & 1.00 & - & - & - & - \\
\hline & $(0.00)^{\mathrm{c}}$ & - & - & - & - & - \\
\hline & 0.13 & -0.17 & 1.00 & - & - & - \\
\hline \multirow[t]{2}{*}{ Private school (kindergarten) } & $(0.00)$ & $(0.00)$ & - & - & - & - \\
\hline & 0.12 & 0.17 & -0.01 & 1.00 & - & - \\
\hline \multirow[t]{2}{*}{ ROSC } & $(0.01)$ & $(0.00)$ & $(0.85)$ & - & - & - \\
\hline & 0.58 & 0.62 & 0.06 & 0.22 & 1.00 & - \\
\hline \multirow[t]{2}{*}{ Primary madrasa } & $(0.00)$ & $(0.00)$ & $(0.16)$ & $(0.00)$ & - & - \\
\hline & 0.37 & 0.38 & 0.08 & 0.25 & 0.41 & 1.00 \\
\hline BRAC & $(0.00)$ & $(0.00)$ & $(0.08)$ & $(0.00)$ & $(0.00)$ & - \\
\hline
\end{tabular}

Notes: (a) ROSC denotes Reaching-out-of-School.

(b) BRAC denotes Bangladesh Rural Advancement Committee.

(c) $P$-values are reported in parentheses.

Lastly, separating demand- and supply-side factors is difficult using cross-sectional data. Ideally, we want to study location choice of schools or madrasas that were recently set up as a function of initial characteristics of the region where they are located. Otherwise, the supply of government schools can be conditioned on the availability of non-state schools as much as the location of non-state schools being explained by the (un)availability of state schools. However, the institutional structure of Bangladesh's education sector minimises the concern over simultaneity bias in the data. On the one hand, almost all of the government primary schools were set up on or before 1970; that is, long before BRAC non-formal school program was launched (see Table A2). On the other hand, all ROSC schools have been set up recently (that is, on or after 2008). Similarly, each BRAC school operates on a 4 year cycle, so that at any point in time, the stock of BRAC schools reflects those recently in operation. Therefore, current locations of government schools cannot be influenced by the placement of non-state schools such as ROSC and BRAC. The reverse causality problem does not arise because the stock of government schools is largely historical. Hence, indicators capturing the presence of government schools essentially enter as lagged variables in the regression models presented in the next section. ${ }^{20}$

\section{Results}

The main analysis focuses on the total counts of three types of pro-poor schools in the region. Therefore, regression models are estimated using three dependent variables, 
counts of BRAC schools, ROSC schools and primary madrasas, in Tables 3, 4 and 5, which report Poisson regression estimates of determinants of school locations in Bangladeshi sub-districts.

The primary focus is on poverty (measured in terms of population under the lower poverty line). Table 3 reports Poisson regression estimates of school locations with a focus on child population size and poverty rate in the region. Irrespective of the dependent variables used, the coefficient on the poverty variable is positive and significant in all regressions. This finding is not surprising, given that both BRAC and ROSC schools do not charge any fee, while madrasas only charge a nominal fee, hence all being more attractive to children from poor families. ${ }^{21}$ However, the coefficient on the poverty variable is largest in ROSC school count regression. This is true even after controlling for district dummies (see model 2). This confirms that ROSC schools do not simply go to poor districts, they also target poorer sub-districts within a poor district. ${ }^{22}$

My next objective is to test whether school location choice is driven by under-supply of formal schools in the sub-district. To this end, I expand model 2 of Table 3 by additionally allowing for two indicators of public investment in education; namely, presence of primary and secondary government and government-supported schools in the region. Results are reported in Table 4. I use a parsimonious and a detailed specification. In all parsimonious specifications (model 1), the coefficient on the number of government primary schools is significant. While the counts of BRAC and madrasa schools are positively correlated with government primary schools, the opposite is true for ROSC schools-they have a greater concentration in sub-districts where government primary and secondary schools are under-supplied. Turning to the detailed specification (model 2), these results remain unchanged and are supported by observed correlations with other formal non-poor schools. For instance, ROSC schools are also significantly higher in sub-districts where the supply of governmentaided primary schools is limited, while their presence is significantly lower in urbanised sub-districts.

Turning to BRAC schools, there is no evidence to suggest that these non-formal schools strategically place themselves in areas where there is a lack of public 
educational investment. They have a significantly higher presence in sub-districts where the supply of government primary schools is also large (model 1). The effect of government primary schools is washed out once I additionally control for the supply of non-government primary and secondary schools (model 2). In general, regions with more non-government secondary schools attract a large number of primary schools of all types, except madrasas. This is not surprising, considering the fact that primary schools act as feeders to secondary schools. However, in regions with at least one government secondary school, the presence of ROSC schools is ninefold smaller than that of BRAC and madrasa schools. In Bangladesh, there are less than 350 secondary government schools, most of which were set up decades ago and have favoured areas with larger population density and urban facilities. This again confirms the fact that, compared to BRAC, ROSC schools are more likely to avoid areas that have historically benefited from large public investment in education. These results suggest that ROSC schools do a better job in targeting under-provided populations, compared to BRAC (and madrasa) schools. 
Table 3 Poisson Regression Estimates of Determinants of School Locations in Sub-Districts ${ }^{\mathrm{a}}$

\begin{tabular}{|c|c|c|c|c|c|c|}
\hline & \multicolumn{2}{|c|}{ ROSC $^{b}$ school } & \multicolumn{2}{|c|}{$B R A C^{c}$ school } & \multicolumn{2}{|c|}{ Madrasa } \\
\hline & (1) & (2) & (1) & (2) & (1) & (2) \\
\hline \multirow[t]{2}{*}{ \% Population below poverty line in 2005} & 0.085 & 0.052 & 0.009 & 0.011 & 0.022 & 0.009 \\
\hline & $(27.110)^{\mathrm{d} * * e}$ & $(9.900)^{* *}$ & $(7.350)^{* *}$ & $(8.770)^{* *}$ & $(26.040)^{* *}$ & $(4.970)^{* *}$ \\
\hline \multirow[t]{2}{*}{ Number of 6-10 year old children } & 0.034 & 0.048 & 0.017 & 0.019 & 0.017 & 0.015 \\
\hline & $(39.870)^{* *}$ & $(30.400)^{* *}$ & $(44.390)^{* *}$ & $(50.390)^{* *}$ & $(65.850)^{* *}$ & $(29.790)^{* *}$ \\
\hline \multirow[t]{2}{*}{ Dhaka } & -0.056 & - & -0.595 & - & -0.238 & - \\
\hline & $(0.940)$ & - & $(20.070)^{* *}$ & - & $(12.970)^{* *}$ & - \\
\hline \multirow[t]{2}{*}{ Khulna } & 0.346 & - & -0.071 & - & 0.022 & - \\
\hline & $(3.590)^{* *}$ & - & $(2.040)^{*}$ & - & -0.920 & - \\
\hline \multirow[t]{2}{*}{ Chittagong } & -0.228 & - & -0.411 & - & -0.473 & - \\
\hline & $(2.760)^{* *}$ & - & $(12.580)^{* *}$ & - & $(20.560)^{* *}$ & - \\
\hline \multirow[t]{2}{*}{ Barisal } & 0.494 & - & 0.330 & - & -1.553 & - \\
\hline & $(6.100)^{* *}$ & - & $(9.940)^{* *}$ & - & $(31.140)^{* *}$ & - \\
\hline \multirow[t]{2}{*}{ Sylhet } & 0.870 & - & -0.790 & - & -0.249 & - \\
\hline & $(9.510)^{* *}$ & - & $(15.320)^{* *}$ & - & $(8.330)^{* *}$ & - \\
\hline \multirow[t]{2}{*}{ Constant } & -2.865 & -3.762 & 2.450 & 3.279 & 2.740 & 1.514 \\
\hline & $(18.320)^{* *}$ & $(3.710)^{* *}$ & $(44.390)^{* *}$ & $(38.230)^{* *}$ & $(69.450)^{* *}$ & $(7.320)^{* *}$ \\
\hline District dummies & No & Yes & No & Yes & No & Yes \\
\hline Observations & 485.000 & 485.000 & 485.000 & 485.000 & 485.000 & 485.000 \\
\hline Pseudo $R^{2}$ & 0.170 & 0.490 & 0.320 & 0.520 & 0.310 & 0.470 \\
\hline
\end{tabular}

Notes: (a) Omitted district category is Rajshahi.

(b) ROSC denotes Reaching-out-of-School.

(c) BRAC denotes Bangladesh Rural Advancement Committee.

(d) Absolute values of $z$-statistics are in parentheses.

(e) * denotes significance at the 5 per cent level and ** denotes significance at the 1 per cent level. 
Table 4 Poisson Regression Estimates of Determinants of Primary School Locations in Sub-Districts Controlling for 'Supply of Government (and Government-Aided) Schools'

\begin{tabular}{|c|c|c|c|c|c|c|}
\hline & \multicolumn{2}{|c|}{ ROSC school $^{2}$} & \multicolumn{2}{|c|}{$B R A C^{b}$ school } & \multicolumn{2}{|c|}{ Madrasa } \\
\hline & $(1)^{a}$ & $(2)^{b}$ & $(1)^{a}$ & $(2)^{b}$ & $(1)^{a}$ & $(2)^{b}$ \\
\hline \multirow[t]{2}{*}{ \% Population below poverty line in 2005} & 0.047 & 0.048 & 0.008 & 0.004 & 0.005 & 0.004 \\
\hline & $(8.640)^{c * * d}$ & $(7.580)^{* *}$ & $(5.580)^{* *}$ & $(2.160)^{*}$ & $(2.500)^{*}$ & $(1.840)^{+}$ \\
\hline \multirow[t]{2}{*}{ Number of 6-10 year old children } & 0.081 & 0.079 & 0.011 & 0.009 & 0.004 & 0.001 \\
\hline & $(25.950)^{* *}$ & $(23.410)^{* *}$ & $(20.480)^{* *}$ & $(16.590)^{* *}$ & $(5.390)^{* *}$ & $(1.070)$ \\
\hline \multirow[t]{2}{*}{ Government secondary schools present } & -0.928 & -0.921 & -0.120 & -0.059 & -0.085 & -0.054 \\
\hline & $(16.88)^{* *}$ & $(14.150)^{* *}$ & $(7.790)^{* *}$ & $(3.570)^{* *}$ & $(3.720)^{* *}$ & $(2.230)^{*}$ \\
\hline \multirow[t]{2}{*}{ Number of government primary schools } & -1.269 & -1.542 & 0.621 & 0.018 & 0.823 & 0.269 \\
\hline & $(10.140)^{* *}$ & $(10.780)^{* *}$ & $(23.870)^{* *}$ & $(0.540)$ & $(22.520)^{* *}$ & $(5.710)^{* *}$ \\
\hline \multirow[t]{2}{*}{ Urban } & - & -0.007 & - & -0.010 & - & 0.003 \\
\hline & - & $(1.900)^{+}$ & - & $(12.620)^{* *}$ & - & $(3.010)^{* *}$ \\
\hline \multirow[t]{2}{*}{$\begin{array}{l}\text { Number of non-government secondary } \\
\text { schools }\end{array}$} & - & 0.620 & - & 0.590 & - & -0.058 \\
\hline & - & $(4.840)^{* *}$ & - & $(18.210)^{* *}$ & - & $(1.230)$ \\
\hline \multirow[t]{2}{*}{$\begin{array}{l}\text { Number of non-government primary } \\
\text { schools }\end{array}$} & - & -0.207 & - & 0.113 & - & 0.770 \\
\hline & - & $(3.270)^{* *}$ & - & $(6.170)^{* *}$ & - & $(26.210)^{* *}$ \\
\hline \multirow[t]{2}{*}{ Constant } & 1.606 & 0.507 & 0.106 & 1.538 & -1.169 & -0.356 \\
\hline & $(1.840)^{+}$ & $(0.440)$ & $(0.690)$ & $(9.780)^{* *}$ & $(5.510)^{* *}$ & $(1.230)$ \\
\hline $\mathrm{N}$ & 485.000 & 468.000 & 485.000 & 468.000 & 485.000 & 468.000 \\
\hline Pseudo $R^{2}$ & 0.520 & 0.520 & 0.550 & 0.580 & 0.540 & 0.650 \\
\hline District dummies $^{\mathrm{e}}$ & Yes & Yes & Yes & Yes & Yes & Yes \\
\hline
\end{tabular}

Notes: (a) ROSC denotes Reaching-out-of-School.

(b) BRAC denotes Bangladesh Rural Advancement Committee.

(c) Absolute values of $z$-statistics are in parentheses.

(d) + denotes significance at the 10 per cent level, * denotes significance at the 5 per cent level and ** denotes significance at the 1 per cent level.

(e) In total, there are only about 350 government secondary schools (or at most one per sub-district) in Bangladesh. For this reason, I use a dummy indicator to capture access to government schools instead of totalling their counts at the sub-district level. 
It should be noted that, even after detailed control for supply of alternative formal schools, the coefficient on the poverty variable still remains significant. Moreover, size of the coefficient does not fall in specification (2) (when we compare to model 2 estimates in Table 3). In Table 4, for a 1 per cent increase in the population living below the poverty line in the sub-district, the difference in the logs of expected counts of ROSC schools is expected to increase by 0.047 , given the other predictor variables in model (1) are held constant. However, the increase is much smaller in case of BRAC and madrasa schools; that is, respectively, 0.008 and 0.005 (see model 1 of Table 4). This implies that the observed poverty effect is not a proxy for underprovision of formal schools in the sub-district. However, it is possible that these economically poor districts also lack public infrastructure which increases the cost of attending formal schools. Households in these districts may remain exposed to economic shocks or have poor access to roads. These may increase direct, as well as indirect, costs of school attendance. The ROSC schools may therefore excel by locating in poor sub-districts that are under-developed in terms of infrastructure provision.

To test this (as well as examine the influence of non-income dimensions of poverty) formally, I revisit estimates in Table 3 by including a host of proxies for remoteness, transport access and economic development. Results are reported in Table 5, where I additionally control for geographical isolation (travel distance to the capital and distance from nearest road), exposure to natural disaster, proportion of illiterate household heads, households with access to good toilet and a proxy for local financial development (measured in terms of total number of bank branches).

Control for the level of infrastructure washes out the effect of local poverty as a determinant of school concentration in the region (see model 1, Table 5). Consistent with the earlier findings from Table 4, BRAC schools are less likely to be in locations that are far from the city. On the other hand, ROSC schools and madrasas are found more in distant regions, although the correlation is only significant in case of the former. These patterns also hold when using an alternative measure of remoteness, distance to nearest road: ROSC schools have significantly higher presence in locations where the distance to nearest road is higher, while the opposite is true for BRAC schools. Regions with more banks seem to have a large concentration of 
BRAC schools, while the opposite is true for ROSC schools and madrasas. In general, ROSC schools have a more systematic association with various proxies of local poverty, compared to BRAC schools. They have a greater presence in sub-districts with poor communication infrastructure (for example, being further away from the nearest road and city) and geographical vulnerability to natural disasters. The ROSC schools also have a higher concentration in sub-districts that are financially less developed or have fewer working toilets; the opposite result holds for BRAC schools.

In contrast to ROSC and BRAC schools, the findings on madrasas are somewhat mixed. Madrasa concentration is positively associated with a number of proxies of poverty and infrastructure development such as higher proportion of households with an illiterate head, smaller proportion of households with good toilets and large number of bank branches per 1,000 people. Only in case of one indicator of poverty, vulnerability to natural disaster, is the association negative and significant. In case of two other indicators, travel time to nearest major city and distance to nearest road, the effects are not significant even though both indicators are significantly associated with expected counts of ROSC and BRAC schools (the association being positive and negative, respectively). Nonetheless, the poverty connection still holds for madrasas-even after detailed control for infrastructure effects in Table 5, the coefficient on local poverty (that is, percentage of population below poverty line in 2005) remains significant in madrasa regression.

The finding that location decision of BRAC schools is negatively related with low infrastructure runs contrary to the popular notion that BRAC schools charge no fee and manage with little to no facilities (The Economist 2012; 23 Rosenberg 2013; Macmillan 2015; Smith, Fraser and Schauerhammer 2015). However, as explained in Section 3, operational considerations may discourage BRAC to set up schools in under-provided areas. In the context of Bangladesh, the major input to education, female teachers, is the main constraint to delivering educational services in rural areas. It is possible that low-infrastructure areas also have lower proportion of Table 
5 Poisson Regression Estimates of Determinants of School Locations in SubDistricts

\begin{tabular}{|c|c|c|c|c|c|c|}
\hline & \multicolumn{2}{|c|}{ ROSC ${ }^{a}$ school } & \multicolumn{2}{|c|}{$B R A C^{b}$ school } & \multicolumn{2}{|c|}{ Madrasa } \\
\hline & (1) & (2) & (1) & (2) & $(1)$ & (2) \\
\hline \multirow[t]{2}{*}{ \% Population below poverty line ${ }^{\mathrm{C}}$ in 2005} & 0.012 & 0.006 & -0.002 & 0.003 & 0.005 & 0.007 \\
\hline & $(1.510)^{\mathrm{d}}$ & $(0.740)$ & $(0.920)$ & $(1.580)$ & $(1.840)++^{\mathrm{e}}$ & $(1.090)$ \\
\hline \multirow[t]{2}{*}{ Number of 6-10 year old children ${ }^{j}$} & 0.062 & 0.062 & 0.018 & 0.019 & 0.016 & 0.021 \\
\hline & $(28.920)^{* *}$ & $(29.040)^{* *}$ & $(36.200)^{* *}$ & $(38.070)^{* *}$ & $(24.100)^{* *}$ & $(13.270)^{* *}$ \\
\hline \multirow[t]{2}{*}{ Travel time to nearest major city ${ }^{\mathrm{f}}$} & 0.067 & 0.074 & -0.008 & -0.010 & 0.004 & 0.007 \\
\hline & $(7.730)^{* *}$ & $(8.320)^{* *}$ & $(2.800)^{* *}$ & $(3.560) * *$ & (1.020) & $(0.830)$ \\
\hline \multirow[t]{2}{*}{ Distance to nearest road ${ }^{\mathrm{g}}$} & 0.233 & 0.299 & -0.196 & -0.192 & -0.005 & 0.160 \\
\hline & $(1.720)+$ & $(2.210)^{*}$ & $(5.540)^{* *}$ & $(5.430)^{* *}$ & $(0.110)$ & $(1.570)$ \\
\hline \multirow[t]{2}{*}{ Vulnerability to natural disaster ${ }^{\mathrm{h}}$} & 0.015 & 0.014 & -0.002 & -0.002 & -0.002 & 0.000 \\
\hline & $(12.290)^{* *}$ & $(12.020)^{* *}$ & $(7.220)^{* *}$ & $(5.220)^{* *}$ & $(4.090)^{* *}$ & $(0.130)$ \\
\hline \multirow[t]{2}{*}{ Proportion of households with an illiterate head } & 0.061 & 0.082 & 0.008 & -0.023 & 0.010 & -0.019 \\
\hline & $(8.390)^{* *}$ & $(9.290)^{* *}$ & $(0.270)$ & $(10.120)^{* *}$ & $(4.230)^{* *}$ & $(2.900)^{* *}$ \\
\hline \multirow[t]{2}{*}{ Proportion of households with good toilets } & -0.042 & -0.039 & -0.010 & -0.012 & -0.006 & 0.003 \\
\hline & $(10.930)^{* *}$ & $(10.190)^{* *}$ & $(9.540)^{* *}$ & $(11.870)^{* *}$ & $(4.800)^{* *}$ & $(1.220)$ \\
\hline \multirow[t]{2}{*}{ Number of bank branches per 1,000 people } & -0.071 & -0.065 & 0.005 & 0.004 & -0.005 & -0.014 \\
\hline & $(11.090)^{* *}$ & $(10.130)^{* *}$ & $(3.760)^{* *}$ & $(0.120)$ & $(2.650)^{* *}$ & $(3.410) * *$ \\
\hline \multirow[t]{2}{*}{ Female literacy $^{\mathrm{i}}(\%)$} & - & -0.036 & - & 0.041 & - & 0.027 \\
\hline & - & $(4.080)^{* *}$ & - & $(16.750)^{* *}$ & - & $(3.890) * *$ \\
\hline \multirow[t]{2}{*}{ Constant } & -4.265 & -3.215 & 4.072 & 2.875 & 1.461 & -2.453 \\
\hline & $(3.990)^{* *}$ & $(2.930)^{* *}$ & $(32.460)^{* *}$ & $(19.760)^{* *}$ & $(5.980)^{* *}$ & $(2.310)^{*}$ \\
\hline $\mathrm{N}$ & 485.000 & 484.000 & 485.000 & 484.000 & 485.000 & 484.000 \\
\hline Pseudo $R^{2}$ & 0.540 & 0.540 & 0.530 & 0.550 & 0.480 & 0.490 \\
\hline District dummies & Yes & Yes & Yes & Yes & Yes & Yes \\
\hline
\end{tabular}

Notes: (a) ROSC denotes Reaching-out-of-School.

(b) BRAC denotes Bangladesh Rural Advancement Committee.

(c) Sub-district figures on population below the poverty line are from World Food Program and are based on local poverty maps. This relates to the proportion of people in the sub-district living below the national lower poverty line. This is used by the Bangladesh Bureau of Statistics to measure extreme poverty in the country, based on a food basket providing minimal nutritional requirements corresponding to 2,122 kcal/day/person. For further details, see Narayan, Yoshida and Zaman (2007) and Yoshida (2009).

(d) absolute values of z-statistics are in parenthesis.

(e) + denotes significance at the 10 per cent level, * denotes significance at the 5 per cent level and ** denotes significance at the 1 per cent level.

(f) 'Travel time to nearest major city' is in minutes (16 major cities were selected) and is for the year 2000; data source: Local Government Engineering Department (LGED).

(g) 'Distance to nearest road' is for the year 2000 and measures percentage of areas under each subdistrict within $2.5 \mathrm{~km}$ from major roads (national highway, regional highway, feeder road A and feeder road B); data source: LGED.

(h) 'Vulnerability to natural disaster' is defined as percentage of areas within each sub-district prone to severe disaster: flood, river erosion, drought and cyclone; data source: LGED and the Bangladesh

Space Research and Remote Sensing Organization.

(i) Female (aged 7 years or older) literacy data are from 2001 population Census.

(j) School age data are from 2011 Bangladesh Bureau of Statistics Census. 
potential teachers. To this end, Table 5 additionally reports a specification (see model 2) that controls for female literacy rate in the sub-district. ${ }^{24}$ In case of ROSC schools, the coefficient on the literacy variable is negative and significant. But, it is positive and significant in case of BRAC schools. The bank variable also loses significance in model 2.

Overall, ROSC schools have higher presence in sub-districts with poor infrastructure, implying that they are better targeted, while BRAC schools concentrate in betterdeveloped parts of a poor district. This finding is consistent with the existing literature on NGO branch placement in Bangladesh (for example, Mallick and Nabin 2011). Mallick and Nabin find that NGOs in Bangladesh operate in locations with good physical infrastructure and better productive and marketing opportunities and they do so to minimise operating costs. Using data from northern Bangladesh, they find that NGO coverage in a village (measured as number of working NGOs) decreased with distance of the village from marketplace and increased with adoption of modern irrigation methods and soil quality. The NGOs did not consider poverty incidence in the village. ${ }^{25}$ The findings on BRAC school location are also consistent with the fact that these schools are run primarily by locally recruited female teachers and are therefore set up in areas with adequate supply of female graduates of secondary schools. This pattern of location is similar to that of for-profit private schools in Pakistan that have emerged in locations that have previously benefited from public investment in female secondary schools (Andrabi, Das and Khwaja 2013).

\section{Conclusions}

Non-governmental organisations play an increasingly important role in the delivery of public services in developing countries. But, little systematic evidence is available about where in Bangladesh NGO-run schools open alongside government-run nonformal schools. I present a comparative analysis of location choice of one of the largest non-formal school models in Bangladesh, BRAC-run primary schools and its replication, ROSC project schools, and compare both with location choice of another pro-poor school-madrasa. Not-for-profit, non-state schools are popular options for educating out-of-school children in poor countries. By way of studying the empirical determinants of geographical location of BRAC vis-à-vis ROSC schools in 
Bangladesh, I fill an important gap in the international literature on the strategic choice of NGO-run development programs in low income countries.

A number of findings follow from the analysis. First, BRAC, ROSC and madrasa schools are all found to have a significantly high concentration in poor areas. However, I find that ROSC schools have higher concentration in poor sub-districts, compared to BRAC (and madrasa) schools. In particular, the ROSC program has greater presence in regions that are remote (in terms of access to cities and roads), have fewer banks and working toilets and are vulnerable to natural disasters. On the contrary, location decision of BRAC schools is negatively related with low infrastructure. Second, ROSC schools have a greater presence in regions that are under-served by government and government-supported formal primary schools. On the other hand, the supply of BRAC schools (and madrasas) is significantly and positively associated with the number of formal primary schools. This analysis also shows that the positive association between BRAC school counts and infrastructure is partly explained by the fact that well-provided areas also have higher female literacy rate, making it easier for BRAC to recruit female teachers. However, no such evidence is present in case of ROSC schools. These findings suggest that, contrary to the popular media commentaries (for example, Rosenberg 2013), BRAC schools behave strategically, compared to ROSC schools, when catering to the educationally underprivileged population. The latter does a better job in targeting regions where socioeconomic circumstances are most likely to keep children out of school.

This study therefore adds to the existing evidence on the entry of NGOs in poor pockets of relatively well-developed areas, rather than in remoter, less-developed regions (Sharma and Zeller 1999) and into communities that are already being catered for by other service providers (Fruttero and Gauri 2005). The findings imply that evaluation of the performance of NGO programs is likely to suffer from positive selection bias (Chowdhury and Bhuiya 2004). The evidence also cautions against the strategy where developing country governments and aid agencies consider NGO-run pro-poor schools as the most effective means of bringing children from isolated communities into mainstream education. Further low-cost innovation in NGO service delivery models ${ }^{26}$ should be emphasised to ensure that children in difficult-to-reach communities are equally served by NGO programs. Another example would be 
BRAC's encouragement and execution of research studies such as this one in order to improve school targeting in practice and bring it more into line with its objective of reaching the poorest and most deprived families.

\section{References}

Ahmed, A. U. 2006, Evaluating the Reaching Out-Of-School Children Project in Bangladesh: A Baseline Study, International Food Policy Research Institute, Washington, DC.

Ahmed, M. 2008, 'Policy options in non-formal education', in Policy-Making in Education Reforms in Developing Countries: Policy Options and Strategies, eds W. K. Cummings and J. H. Williams, Rowman \& Littlefield, Lanham, Maryland.

Andrabi, T., Das, J. and Khwaja, A. 2013, 'Students today, teachers tomorrow? Identifying constraints on the provision of education', Journal of Public Economics, vol. 100, pp. 1-14.

Ardt, K., Hastings, C., Hopkins, K., Knebel, R., Loh, J. and Woods, R. 2005, 'Report on primary education in Bangladesh: Challenges and successes', paper presented to the Third Summit on South Asian Development Hosted by South Asian Society for Regional Cooperation, 19 May. viewed 01 May 2016, http://rih.stanford.edu/rosenfield/resources/Primary\%20Education\%20in\%20B angladesh.pdf

Arif, G. M. and Saqib, N. U. 2003, 'Production of cognitive and life skills in public, private, and NGO schools in Pakistan', Pakistan Development Review, vol. 42, pp. 1-28.

Asadullah, M. N., Chakrabarti, R. and Chaudhury, N. 2015, 'What determines religious school choice? Theory and evidence from rural Bangladesh', Bulletin of Economic Research, vol. 67, 186-207.

Asadullah, M. N. and Chaudhury, N. 2016, 'To madrasahs or not to madrasahs: The question and correlates of enrolment in Islamic schools in Bangladesh', International Journal of Educational Development, vol. 49, pp. 55-69.

Asadullah, M. N., Chaudhury, N. and Dar, A. 2007, 'Student achievement conditioned upon school selection: Religious and secular secondary school quality in Bangladesh', Economics of Education Review, vol. 26, pp. 64859.

Asadullah, M. N. and Chaudhury, N. 2009, 'Holy alliances: public subsidies, Islamic high schools, and female schooling in Bangladesh', Education Economics, vol. 17, pp. 377-394.

Asadullah, M. N., Savoia, A. and Mahmud, W. 2014, 'Paths to development: Is there a Bangladesh surprise?’, World Development, vol. 62, pp. 138-54.

Barrow, L. 2002, 'Private school location and neighborhood characteristics', Federal Reserve Bank of Chicago Working Paper no. 2002-27, Chicago, Illinois.

Bangladesh Rural Advancement Committee 2009, BRAC Annual Report 2009, Dhaka, Bangladesh, viewed March 2011, $<$ http://www.brac.net/sites/default/files/Annual-Report-2009/brac-ar-2009programme-update.pdf.

Barr, A. and Fafchamps, M. 2006, "A client-community assessment of the NGO sector in Uganda," Journal of Development Studies, vol. 42, pp. 611-639. 
Brass, J. N. 2012, 'Why do NGOs go where they go? Evidence from Kenya', World Development, vol. 40, pp. 387-401.

Chabbott, C. 2006, Meeting EFA: Bangladesh Rural Advancement Committee (BRAC) Primary Schools, Academy for Education Development, Washington, DC.

Chabbott, C. 2014, Institutionalizing Health and Education for All: Global Goals, Innovations, and Scaling Up, Teachers College Press, New York.

Chowdhury, A. M. R. and Bhuiya, A. 2004, 'The wider impacts of BRAC poverty alleviation programme in Bangladesh', Journal of International Development, vol. 16, pp. 369-86.

Coombs, P. H. and Ahmed M. 1974, Attacking Rural Poverty: How Non-Formal Education Can Help, John Hopkins University Press, Baltimore, Maryland.

Dang, H.-A., Sarr, L. and Asadullah, M. N. 2011, 'School access, resources, and learning outcomes: Evidence from a non-formal school program in Bangladesh', Institute for the Study of Labor Discussion Paper no. 5659, Bonn.

Department for International Development 2013, Education: Improving Learning, Expanding Opportunities, Department for International Development, London.

DeStefano, J., Schuh Moore, A.-M., Balwanz, D. and Hartwell, A. 2007, 'Reaching the underserved: Complementary models of effective schooling', USAID and Academy for Educational Development Equip 2 Project Working Paper, Washington, DC.

Directorate of Primary Education 2012a, Annual School Census 2011, DPE, Government of Bangladesh, Dhaka, Bangladesh.

Directorate of Primary Education 2012b, Bangladesh Primary Education: Annual Sector Performance Report (ASPR) 2012, DPE, Government of Bangladesh, Dhaka, Bangladesh.

Downes, T. and Greenstein, S. M. 1996, 'Understanding the supply decisions of nonprofits: The location of private schools', RAND Journal of Economics, vol. 27, no. 2, pp. 365-90.

Downes, T. and Greenstein, S. M. 2002, 'Entry into the schooling market: How is the behaviour of private suppliers influenced by public sector decisions?', Bulletin of Economic Research, vol. 54, pp. 341-71.

Essuman, A. and Bosumtwi-Sam, C. 2013, 'School feeding and educational access in rural Ghana: Is poor targeting and delivery limiting impact?’, International Journal of Educational Development, vol. 33, pp. 253-62.

Evans, A. 2006, 'Understanding madrasahs: How threatening are they?', Foreign Affairs, vol. 85, no. 1, p. 9-16.

Farrell, J. P. 2004, The Egyptian Community Schools Program: A Case Study, Academy for Education Development, Washington, DC, viewed January 2016, <http://www.equip123.net>.

Farrell, J. P. and Hartwell, A. 2008, Planning for Successful Alternative Schooling: A Possible Route to Education for All, International Institute for Education Planning Research Paper, Planning for Successful Alternative Schooling: A Possible Route to Education for All, Paris.

Fruttero, A. and Gauri, V. 2005, 'The strategic choices of NGOs: Location decisions in rural Bangladesh', Journal of Development Studies, vol. 41, pp. 759-87.

Glaeser, Edward L. and Shleifer, A. 2001, 'Not-for-Profit Enterpreneurs.' Journal of Public Economics, vol. 81, no. 1, pp. 99-115. 
Griswood, E. 2005, ‘The next Islamist revolution?’, New York Times Magazine, 23 January. Accessed January 2016 http://www.nytimes.com/2005/01/23/magazine/the-next-islamistrevolution.html?_r=0

Haiplik, B. 2002, 'BRAC's NFPE Program: Focus on teacher development issues', paper presented to the Annual Meeting of the Comparative and International Education Society, Orlando, Florida, 6-9 March.

Haiplik, B. M. 2004, 'An educational success story from Bangladesh: Understanding the BRAC non-formal primary education model and its teacher training and development system', unpublished $\mathrm{PhD}$ thesis, The Ontario Institute for Studies in Education, University of Toronto.

Hossain, N. and Sengupta, A. 2009, 'Thinking big, going global: The challenge of BRAC’s global expansion', Institute of Development Studies Working Paper no. 339, University of Sussex.

Jacinto, A. 2014, '1,200 learning centers for 40,000 kids open in ARMM', Manila Times, 4 June, viewed April 2016, <http://www.manilatimes.net/1200learning-centers-for-40000-kids-open-in-armm/101642/>.

Kabeer, N., Nambissan, G. B. and Subrahmanian, R. 2003, Child Labour and the Right to Education in South Asia: Needs versus Rights, Sage, New Delhi.

Khan, S. R. and Kiefer, D. 2007, 'Educational production functions for rural Pakistan: A comparative institutional analysis', Education Economics, vol. 15, pp. 32742.

Kochar, A. 2004, 'Do schooling policies contribute to schooling inequality? School location policies in rural India', SIEPR policy brief. Stanford Institute for Economic Policy Research, Stanford University, Stanford, California.

Li, W., Ahmed, M., Khan, Q. and Hongwei, M. 2016, Education and Training for Rural Transformation: Skills, Jobs, Food and Green Future to Combat Poverty, Sage, New Delhi.

McEwan, P. J. 1998, 'The effectiveness of multigrade schools in Colombia', International Journal of Educational Development, vol. 18, pp. 435-52.

Macmillan, S. 2015, 'Glorious failure: The joy of learning from your mistakes', The Guardian, $30 \quad$ March. Accessed January 2016 https://www.theguardian.com/global-development-professionalsnetwork/2015/mar/30/glorious-failure-joy-learning-from-your-mistakes

Mallick, D. and Nabin, M. 2011, 'Where NGOs go and do not go?', Research Monograph Series No. 45, Research and Evaluation Division, BRAC, Dhaka.

Narayan, A., Yoshida, N. and Zaman, H. 2007, 'Trends and patterns of poverty in Bangladesh in recent years', unpublished paper, South Asia Region, World Bank .

Nath, S. 2002, 'School evaluation mechanism in BRAC education programme', Paper presented at the Asian Network of Training and Research Institutions in Educational Planning (ANTRIEP) Policy Seminar, July 2-4, Kuala Lumpur.

Pal, S. 2010, 'Public infrastructure, location of private schools and primary school attainment in an emerging economy', Economics of Education Review, vol. 29, pp. 783-94.

Psacharopolous, G., Rojas, C. and Velez, E. 1993, 'Achievement evaluation of Colombia's "Escuela Nueva”: Is multigrade the answer?', Comparative Education Review, vol. 37, pp. 263-76.

Rashid, S., Chowdhury, M. and Bhuiya, A. 1995, 'An inside look at two BRAC schools in Matlab’, BRAC-ICDDR,B Working Paper no. 8, Dhaka. 
Ravallion, M. and Wodon, Q. 2000, 'Banking on the poor? Branch location and nonfarm rural development in Bangladesh', Review of Development Economics, vol. 4, pp. 121-39.

ROSC Project Office Unit 2009, ROSC Monitoring Cell Report, Dhaka, Bangladesh.

Rosenberg, T. 2013, 'Where private school is not a privilege', New York Times, 8 May, January 2016. http://opinionator.blogs.nytimes.com/2013/05/08/whereprivate-school-is-not-a-privilege/.

Sarr, L. R., Dang, H.-A., Chaudhury, N., Parajuli, D. and Asadullah, M. N. 2010, Reaching Out-Of-School Children Project: Evaluation Report, World Bank Working Paper no. 81038, Washington, DC.

Sharma, M. and Zeller, M. 1999, 'Placement and outreach of group-based credit organizations: The cases of ASA, BRAC, and PROSHIKA in Bangladesh', World Development, vol. 27, pp. 2,123-36.

Smith, B., Fraser, E. and Schauerhammer, V. 2015, Final Report 2015: Documenting the Development and Implementation of the Strategic Partnership Arrangement between BRAC, DFID and DFAT, Social Development Direct, London.

Sud, P. 2010, 'Can non-formal education keep working children in school? A case study from Punjab, India', Journal of Education and Work, vol. 23, pp. 1-26.

Sukontamarn, P. 2005, 'The entry of NGO schools and girls' educational outcomes in Bangladesh', Political Economy and Public Policy Series (PEPP Working Paper no 10, London School of Economics and Political Science.

Tran, M. 2012, 'Bangladesh’s Brac receives large aid boost from UK and Australia', The Guardian, 14 June, viewed January 2016, https://www.theguardian.com/global-development/2012/jun/14/bangladeshbrac-aid-uk-australia

United Nations Children's Fund 2009, Situation Assessment and Analysis of Children and Women in Bangladesh, UNICEF, Dhaka, Bangladesh, viewed January 2016, <http://www.unicef.org/bangladesh/BD_Sitan_2009_lowres.pdf > .

United Nations Development Programme 2013, Human Development Report 2013 The Rise of the South: Human Progress in a Diverse World. New York.

Unson, J. 2015, 'Australia's education efforts in Mindanao hailed', Philippine Star, 16 December. Accessed January 2016, http://www.philstar.com/nation/2015/12/16/1533283/australias-educationefforts-mindanao-hailed

Van Domelen, J. 2007, 'Reaching the poor and vulnerable: Targeting strategies for social funds and other community-driven programs', Social Protection Discussion Paper no. 0711, World Bank, Washington, DC.

Wadood, S. N., Mahmoud, C. S. and Khalily, M. A. B. 2012, 'Location decision of microfinance institutions in Bangladesh', unpublished paper, Institute of Microfinance.

Waldman, A. 2003, 'Helping hand for Bangladesh's poor', New York Times, 25 March, viewed January 2016, <http://www.nytimes.com/2003/03/25/world/helping-hand-for-bangladesh-spoor.html $>$.

Weisbrod, B. A. 1975, 'Toward a theory of the voluntary nonprofit sector in a threesector economy', in Altruism, Morality and Economic Theory, ed. E. S. Phelps, Russell Sage Foundation, New York. Reprinted in Rose-Ackerman, S. (ed.) 1986, The Economics of Nonprofit Institutions: Studies in Structure and Policy, Oxford University Press, Oxford. 
Werker, E. and Ahmed, F. Z. 2008, 'What do nongovernmental organizations do?', Journal of Economic Perspectives, vol. 22, no. 2, pp. 73-92.

Alamgir, Dewan; Annamalai, Nagavalli; Appasamy, Irajen; Hasan, Mirza Hamid; Hossain, Naomi Therese; Khan, Safi Rahman; Matsaert, Frank; Rasmussen, Stephen F.; Zaman, Hassan; Zannath, Suraiya 2006, 'Economics and governance of nongovernmental organizations in Bangladesh', Bangladesh Development Series Paper no. 11, World Bank, Washington, DC, viewed January 2016, $<$ http://siteresources.worldbank.org/BANGLADESHEXTN/Resources/NGOre port_Dev_Series.pdf>.

World Bank 2010, 'Secondary school madrasahs in Bangladesh: Incidence, quality and implications for reform', Bangladesh Development Series Paper no. 27, World Bank, Washington, DC.

World Bank 2013, Seeding Fertile Ground: Education that Works for Bangladesh, World Bank, Washington, DC.

Yoshida, N. 2009, 'Updating Bangladesh poverty maps', viewed August 2016, < http://documents.wfp.org/stellent/groups/public/documents/liaison_offices/wf p201414.pdf. 


\section{Table A1 Counts of Schools, Enrolment Share and Examination Performance of Different Types of Primary Schools in Bangladesh}

\begin{tabular}{|c|c|c|c|c|c|c|}
\hline \multirow[b]{3}{*}{ School type } & \multicolumn{4}{|c|}{ Count of school types } & \multirow{3}{*}{$\begin{array}{c}\text { Enrolment } \\
\text { share }^{a} \\
\\
\\
\text { Total students } \\
\text { enrolled } \\
\% \\
\end{array}$} & \multirow{3}{*}{$\begin{array}{c}\text { Student } \\
\text { performance } \\
\text { Pass rate }^{b} \text { in } \\
2011 \\
\text { national } \\
\text { exam } \\
\%\end{array}$} \\
\hline & \multicolumn{2}{|c|}{$\begin{array}{c}\text { Annual school } \\
\text { Census (ASC) } \\
2011 \text { record }\end{array}$} & \multicolumn{2}{|c|}{$\begin{array}{l}\text { National examination } \\
2011 \text { record }\end{array}$} & & \\
\hline & $N$ & $\%$ & $N$ & $\%$ & & \\
\hline Government primary school & 37,670 & 41.99 & 37,651 & 37.90 & 56.02 & 93.67 \\
\hline Registered non-government school & 20,168 & 22.48 & 21,336 & 21.48 & 21.27 & 89.91 \\
\hline Private school (kindergarten) & 10,538 & 11.75 & 11,229 & 11.30 & 7.67 & 93.68 \\
\hline Madrasa $^{\mathrm{c}}$ & 6,428 & 7.17 & 11,519 & 11.59 & 5.75 & 78.01 \\
\hline $\mathrm{BRAC}^{\mathrm{e}}$ & 4,390 & 4.89 & 6,488 & 6.53 & 1.62 & 95.08 \\
\hline $\operatorname{ROSC}^{\mathrm{f}}$ & 2,344 & 2.61 & 2,134 & 2.15 & 0.91 & 46.28 \\
\hline $\begin{array}{l}\text { Non-government unregistered } \\
\text { school }\end{array}$ & 1,486 & 1.66 & 2,237 & 2.25 & 1.50 & 83.83 \\
\hline School (secondary attached) ${ }^{d}$ & 1,494 & 1.67 & 1,770 & 1.78 & 2.58 & 93.79 \\
\hline Other & 5,189 & 5.78 & 4,987 & 5.02 & $\begin{array}{c}2.68 \\
(18.96 \\
\text { million) }\end{array}$ & - \\
\hline Total & 89,707 & 100.00 & 99,351 & 100.00 & 100.00 & - \\
\hline
\end{tabular}

Notes: (a) Enrolment share data are from 2012 ASC.

(b) Pass rate refers to 'Pass rate, as percentage of eligible students' and corresponds to Terminal Examination (national primary school completion exam) 2011.

(c) Madrasa includes those attached to secondary madrasa.

(d) For primary schools, while we know which are attached to a secondary school, we do not know whether they are government aided or not. Hence, this category has been left out.

(e) BRAC denotes Bangladesh Rural Advancement Committee.

(f) ROSC denotes Reaching-out-of-School.

Table A2 Distribution of School Types by Year of Establishment (\%)

\begin{tabular}{|c|c|c|c|c|}
\hline Period of establishment & Government school & ROSC ${ }^{a}$ school & $B R A C^{b}$ school & Madrasa school \\
\hline On/before 1970 & 85.74 & 0 & 0.00 & 23.17 \\
\hline 1971-1980 & 13.22 & 0 & 0.00 & 21.56 \\
\hline 1981-1990 & 0.82 & 0 & 0.00 & 30.48 \\
\hline 1991-2000 & 0.22 & 0 & 0.89 & 19.01 \\
\hline $2001+$ & 0.00 & 100 & 99.11 & 5.93 \\
\hline
\end{tabular}

Source: Data are from 2011 Annual School Census. 


\section{Endnotes}

1. For instance, the Department for International Development of the UK Government, together with AusAID of the Australian Government, has recently entered into a 'Strategic Partnership Arrangement' (SPA) with BRAC to provide GBP358 million over 5 years. A key objective of SPA is to support BRAC's non-formal primary education scheme for 680,000 children (Tran 2012). Similarly, the Australian Government is co-funding 1,200 BRAC schools in the Autonomous Region in Muslim Mindanao of the Philippines (Jacinto 2014).

2. The NGO education sector is highly skewed, with BRAC receiving about three-fourths of donor resources and accounting for a similar share of primary enrolment in NGO schools (Alamgir et al2006). More than 500 NGOs run short or full non-formal primary education programs in Bangladesh which focus on getting children from disadvantaged areas or groups into school and eventually into formal schools from Grade 3 or above.

3. The Economist 2012, 'The path through the fields', 3 November.

4. See Ahmed (2008) and Farrell and Hartwell (2008) for two recent (and qualitative) reviews of nonformal school programs.

5. Chabbott also estimates the cost per BRAC school-completer is \$84, around one-third that of \$246 for those from government public schools.

6. Apart from ROSC model, there are other education programs targeting under-privileged populations. In 2005, the BNFE was established to provide management and oversight of non-formal education initiatives in all 64 districts. It implements the 'Basic Education for the Hard to Reach Urban Working Children' project in six divisional cities and provides quality non-formal and life skills-based education to 0.2 million urban working children and adolescents aged 10 to 14 years (UNICEF 2009).

7. However, day-to-day management of ROSC schools, including activities such as establishment of the school, involves a number of actors such as parents or guardians, a local education officer, a local administrative officer, a NGO representative, the head of the local government primary school, a person from the community and the teacher of the ROSC school.

8. Although BRAC school students do not receive any government financial incentives, the cost is paid for by the school, rather than the household. Bangladesh Rural Advancement Committee pays for everything (for example, textbooks, notebooks, other educational materials and teacher salary), except for the maintenance of the classroom, which is the responsibility of the community (Haiplik 2002; Haiplik 2004; Li et al. 2016). However, students of government schools and non-government registered schools and madrasas have benefited from various financial incentive schemes, such as food-foreducation and cash-for-education, in the last two decades. For a discussion of these schemes, see World Bank (2013).

9. For a detailed comparison of the main characteristics of ROSC schools, compared to BRAC and government primary schools, see Dang, Sarr and Asadullah (2011).

10. International literature on the topic is limited. Two exceptions are Barr and Fafchamps (2006) and Brass (2012). The sub-national NGO location of Brass (2012) corresponds to an area's objective level of need, as well as the convenience of the location for accessing beneficiaries, donors and elite goods. Barr and Fafchamps (2006) find that Ugandan NGOs neglect remote communities, possibly for cost reasons. The evidence also suggests that NGOs operate in the same location, irrespective of presence of other NGO programs.

11. Only in most unusual circumstances, BRAC recruits an unmarried woman. This is because only one teacher is hired for each school, who is expected to teach for a minimum of 3 years. But, in case of unmarried women, the risk of out-migration following marriage is high.

12. Using survey data from five north Indian states, Pal (2010) finds that even after controlling for all other factors, access to village infrastructure facilities is associated with a higher likelihood of having a private school in the community.

13. Habitation size determines school size, which in turn influences characteristics such as the number of teachers employed (Kochar 2004).

14. For Pakistan, Andrabi, Das and Khwaja (2013) find that the boom in private schooling is driven by the availability of low-cost, female teachers. The data show that private schools arise precisely in those villages where there exists a pool of educated women, which in turn are far more common in areas where there exists a government girls' secondary school. Due to a lack of outside opportunities, these women have lower wage rates than educated men. These low wages are then passed onto the students in terms of low fees in the competitive market.

15. Pal (2010) use data on proportion of female teachers and vacant teaching positions in local government schools, pucca school building and school's access to drinking water. 
16. The coverage of ROSC schools, however, remains comparable in 2011 ASC and 2011 Terminal Examination data (2,344 and 2,13, respectively). For instance, under the ROSC project, Directorate of Primary Education coordinates learning centres known as 'Ananda schools'. According to the ROSC report (ROSC Project Office Unit 2009), there were just over 700,000 students enrolled in 21,500 ROSC centres.

17. There is some evidence that suggests that madrasas pay their teachers less, compared to government and private schools (World Bank 2010).

18. At the same time, students of BRAC schools are also from poorer socioeconomic backgrounds, compared to government school students, yet the performance of BRAC schools is on par with student performance of government schools.

19. Indeed, ROSC schools have significantly higher concentration in haor and char areas (Directorate of Primary Education 2012b). Division-wise breakdown of the sub-district level school counts also confirms this. An average sub-district in Barisal has nearly 36 madrasas, compared to only three private schools, 11 BRAC schools and five ROSC schools. Dhaka and Chittagong appear to have the highest concentration of private schools. On the other hand, north-western divisions of Rajshahi and Rangpur have highest concentration of BRAC schools at the sub-district level. Sylhet division (where most haors are located) has a high concentration of ROSC schools and a relatively lower presence of BRAC schools.

20. Nonetheless, in case of madrasas, a sizeable proportion has existed for several decades. For this older sub-set of madrasas, I cannot rule out the possibility of simultaneity bias vis-à-vis the supply of government primary schools in the absence of panel data. This remains a limitation of this study.

21. The finding of higher concentration of madrasas in poorer sub-districts is also consistent with analysis of enrolment data, which consistently report a negative correlation between household income and madrasa attendance (see Asadullah, Chakrabarti and Chaudhury 2015).

22. I plotted data on school counts against out-of-school population in the sub-district. The latter was extracted from 2011 population Census report (results not reported). Compared to BRAC and madrasa schools, number of ROSC schools in a sub-district was positively associated with the out-of-school population, confirming that ROSC schools target regions with large presence of children out of school. 23. The Economist 2012, 'The path through the fields', 3 November.

24. Ideally, we need information on potential teachers (for example, proportion of women aged 18 years and above with minimum secondary school qualifications). Since such data are not available, we use female literacy rate as a proxy.

25. A similar conclusion is reached by Wadood, Mahmoud and Khalily (2012), who examined entry decision of micro-finance institutions in Tangail district of Bangladesh. Both large and small microfinance institutions were found to choose economically more prosperous locations. The studies by Sharma and Zeller (1999), Mallick and Nabin (2011) and Wadood, Mahmoud and Khalily (2012) therefore support the view that pragmatic and organisational concerns, instead of charitable motivations, are the principal determinants of NGO's location decisions in Bangladesh.

26. One example is BRAC's 'floating school' pilot scheme to educate children in remote parts of the Philippines (Jacinto 2014). 